\title{
Performance of Three Primocane-fruiting Red Raspberry Cultivars in Ontario and Québec
}

\author{
Jean-Pierre Privé ${ }^{1}$ J.A. Sullivan, J.T.A. Proctor, and O.B. Allen ${ }^{2}$ \\ Department of Horticultural Science, University of Guelph, Guelph, Ont., N1G 2W1, Canada
}

Additional index words. autumn-bearing, fall-bearing, genotype $\times$ environment, Rubus idaeus

\begin{abstract}
The influence of genotype $\mathrm{x}$ environment interactions on the performance of 'A utumn Bliss' ' $\mathrm{H}$ eritage' and 'R edwing' primocane-fruiting (PF) red raspberry ( $R$ ubus idaeus L.) cultivars was studied at six sites across 0 ntario and $Q$ uebec during 1989 and 1990. Cultivar $\times$ location $\times$ year interactions were found for most vegetative and reproductive components analyzed. 'Autumn Bliss' had the most consistent performance of the three cultivars in all location/year combinations, while 'R edwing' varied greatly between environments. 'H eritage' was always the latest-bearing of the three cultivars and failed to achieve its maximum yield potential in many of the northern locations.
\end{abstract}

Primocane-fruiting (PF), (autumn-fruiting, tipfruiting, fall-bearing, and everbearing) raspberries have been available for more 'than 200 years (Mawe and Abercrombie, 1778), but have failed to gain wide popularity in north temperate regions due to their late maturity. In eastern Canada, the full crop potential of 'Heritage', the most widely grown PF cultivar in the world (Daubeny et al., 1992), is rarely realized, since early fall frosts prevent ripening of the later fruit or poor weather late in the season causes crop loss. The introduction of new, earlier-maturing PF cultivars, such as 'Redwing' (Luby et al., 1987) and 'Autumn Bliss' (Keep et al., 1984), have greater yield potentials in many northern latitudes than do older cultivars.

Genotype $\times$ environment $(\mathrm{G} \times \mathrm{E})$ interactions pose important problems in developing and selecting new cultivars for production in a wide range of environments. This is true of PF red raspberries, as the PF habit is under complex genetic control (Keep, 1988) and is significantly influenced by temperature, daylength, and the length of the growing season (Hoover et al., 1989). Keep (1988) found that the approximate dates of first harvest for 'Heritage' can differ by more than 1 month at various locations, and Hoover et al. (1989) reported that the relative ranking of first and peak harvests differed between environments for 'Heritage' and 'Redwing'. For example, in New York $\left(43^{\circ} \mathrm{N}\right)$, 'Heritage' began production 1 week earlier than 'Redwing', while in Minnesota $\left(45^{\circ} \mathrm{N}\right)$ and Michigan $\left(42.5^{\circ} \mathrm{N}\right)$, 'Redwing' was later by 1 and 2 weeks, respectively. No differences in first harvest dates were reported in Ontario $\left(43^{\circ} \mathrm{N}\right)$ or British Columbia $\left(49^{\circ} \mathrm{N}\right)$. The influence of these $\mathrm{G} \times \mathrm{E}$ interactions on the vegetative and reproductive components of PF red raspberries has not been studied adequately. In addition, due to the recent introduction of many of the earlier-maturing PF cultivars, little literature is available on their performance.

The objectives of this study were to evaluate the performance and the $\mathrm{G} \times \mathrm{E}$ interactions of three $\mathrm{PF}$ red raspberries in north temperate environments.

Received-for publication 7 Oct. 1992. Accepted for publication 30 Oct. 1992. Financial assistance from Agriculture Canada to J.-P.P. while on educational leave is gratefully acknowledged. This study was also supported by the Ontario Ministry of Agriculture and Food and the Ontario Berry Grower's Association. We thank T. Leuty (Harrow), A. Vandenberg (Vineland), S. Van Schyndel (Cambridge), J. Morton (Kemptville), M. Lamarre (Lavaltrie), and B. Hughes (New Liskeard) for their assistance with the yield trials. The cost of publishing this paper was defrayed in part by the payment of page charges. Under postal regulations, this paper therefore must be hereby marked advertisement solely to indicate this fact.

'Corresponding author. Present address: Research Station, Agriculture Canada, P.O. Box 667, Bouctouche, N.B., E0A 1G0, Canada.

${ }^{2}$ Dept. of Mathematics and Statistics,

\section{M aterials and M ethods}

In Spring 1988, tissue-cultured plantlets of 'Autumn Bliss', 'Heritage', and 'Redwing' PF red raspberry plants were planted at six locations (Table 1 ) at $0.6 \mathrm{~m}$ within-row and $1.8 \mathrm{~m}$ between-row spacings. Trellis support was not provided. Plants were mowed in early Spring 1989 and 1990 and fertilized with 34N-0P-0K (135 $\left.\mathrm{kg} \cdot \mathrm{ha}^{-1}\right)$ as a split application (80\% in mid-April and $20 \%$ in midMay) to reduce leaching. Standard cultural practices for pest and weed control were followed in both years (Louws, 1991).

Data collection for full bloom (FB), first harvest, berry count, and yield were recorded at Cambridge and Vineland by the senior author and at New Liskeard, Lavaltrie, Kemptville, and Harrow by local personnel. When harvests were complete, cane density (number of canes/meter row), cane height (cut at soil level and measured from the base of the cane to the terminal bud), cane diameter at soil level, total number of nodes, length of the fruiting section of the cane, number of fruiting laterals, and number of flowers were recorded. Dates of FB were recorded only in 1990. Leaf tissue analysis was performed to ensure proper nutritional levels at each location.

Statistical analysis. The layout was a completely randomized design with five replications (plots) of three cultivars grown at each of the six locations in 1989 and 1990. Yield and yield component data were collected on four representative canes per plot for each cultivar and location. Individual berry weight was averaged, based on the total harvested from four representative canes per plot. The average value of the four canes per plot was then reported on a per cane basis for each of the five replications.

To assess the nature of the $\mathrm{G} \times \mathrm{E}$ interactions, an analysis of variance was performed for each vegetative and reproductive component. The model included location, cultivar and year, and all their interactions. Year was regarded as a "split plot in time" (Steel and Torrie, 1980). These models were fitted using the general linear models (GLM) procedure in SAS/STAT (SAS, 1987).

\section{R esults and Discussion}

Analysis of the vegetative components revealed a significant cultivar $\times$ location $\times$ year interaction for all components except cane diameter. However, cane diameter did have significant location $\mathrm{x}$ cultivar and year $\mathrm{x}$ location interactions.

Cane diameter has been associated with carbohydrate supply

Abreviations: FB, full bloom; PF, primocane fruiting. 
and may have an indirect effect on the fruitfulness of the canes (Crandall et al., 1974). Accordingly, in the present study the location with the largest cane diameters (i.e., Vineland) also had the highest yields (Table 2; Fig. 2B).

Cane densities also varied significantly between cultivars, locations, and years. During the 1989 growing season, the average cane density in the more southerly locations (Cambridge, Vineland, and Harrow) was 45 canes/m row or $86 \%$ greater than the average of the three northerly locations (New Liskeard, Lavaltrie, and Kemptville) (Table 2). In 1990, the third season after planting, cane density increased in the more northerly locations (except 'Heritage' at New Liskeard) but was still lower than the average of the southern locations. 'Autumn Bliss' displayed a stooled habit, while 'Redwing' and 'Heritage' readily produced hedgerows. Averaged over all locations, 'Autumn Bliss', 'Redwing', and 'Heritage' had 27, 35, and 47 canes/m row, respectively. Cane

Table 1. Yield trial locations for red raspberries listed from north to south.

\begin{tabular}{llllll}
\hline & & & & \multicolumn{2}{c}{ GDD $^{z}$} \\
\cline { 5 - 6 } Location & Latitude & Soil type & Soil pH & 1989 & 1990 \\
\hline New Liskeard, Ont. & $47^{\circ} 31^{\prime} \mathrm{N}$ & Humaquept & $6.9-7.2$ & 1612 & 1504 \\
Lavaltrie, Que. & $45^{\circ} 05^{\prime} \mathrm{N}$ & Humic Cryorthod & $6.0-7.2$ & 1955 & 1986 \\
Kemptville, Ont. & $45^{\circ} 01^{\prime} \mathrm{N}$ & Typic Eutrochrept & $6.9-7.3$ & 2025 & 2014 \\
Cambridge, Ont. & $43^{\circ} 26^{`} \mathrm{~N}$ & Typic Hapludalf & $6.3-6.5$ & 1886 & 1939 \\
Vineland, Ont. & $43^{\circ} 11^{\prime} \mathrm{N}$ & Aquic Hapludalf & $6.2-7.1$ & 2228 & 2297 \\
Harrow, Ont. & $42^{\circ} 02^{\prime} \mathrm{N}$ & Typic Hapludalf & $5.7-6.3$ & 2370 & 2429
\end{tabular}

${ }^{\mathrm{z}} \mathrm{GDD}=$ growing degree days with base 5C.

Table 2. Vegetative and reproductive components of 'Autumn Bliss' $(A B)$, 'Heritage' $(H)$, and 'Redwing' (R) PF red raspberries at six locations in 1989 and 1990

\begin{tabular}{|c|c|c|c|c|c|c|c|c|c|c|c|c|c|c|}
\hline \multirow[b]{3}{*}{ Cultivar } & \multicolumn{5}{|c|}{ Cane } & \multirow{2}{*}{\multicolumn{2}{|c|}{$\begin{array}{l}\text { Node } \\
\text { count/ } \\
\text { cane }\end{array}$}} & \multirow{2}{*}{\multicolumn{2}{|c|}{$\begin{array}{l}\text { Length } \\
\text { fruiting } \\
\text { section } \\
\text { (cm) }\end{array}$}} & \multirow{3}{*}{$\begin{array}{c}\text { Fruiting } \\
\text { lateral } \\
\text { no. }^{\mathrm{z}} \\
\text { (cane) }\end{array}$} & \multirow{3}{*}{$\begin{array}{c}\text { Full } \\
\text { bloom } \\
\text { (date) } \\
1990\end{array}$} & \multirow{2}{*}{\multicolumn{2}{|c|}{$\begin{array}{c}\text { Harvest } \\
\text { period } \\
\text { (days) }\end{array}$}} & \multirow{3}{*}{$\begin{array}{c}\text { Berry }^{z} \\
\text { wit } \\
\text { (g) }\end{array}$} \\
\hline & \multicolumn{2}{|c|}{$\begin{array}{c}\text { Count } \\
\text { (per m row) }\end{array}$} & \multicolumn{2}{|c|}{$\begin{array}{c}\mathrm{Ht} \\
(\mathrm{cm})\end{array}$} & \multirow{2}{*}{$\begin{array}{l}\operatorname{Diam}^{2} \\
(\mathrm{~cm})\end{array}$} & & & & & & & & & \\
\hline & 1989 & 1990 & 1989 & 1990 & & 1989 & 1990 & 1989 & 1990 & & & 1989 & 1990 & \\
\hline \multicolumn{15}{|c|}{ New Liskeard } \\
\hline $\mathrm{AB}$ & 15 & 18 & 103 & 111 & 1.0 & 30 & 31 & 39 & 35 & 12 & 30 Aug. & 3 & 3 & 1.3 \\
\hline $\mathrm{H}$ & 36 & 28 & 105 & 117 & 1.0 & 35 & 39 & 29 & 34 & 15 & 5 Sept. & $0^{\mathrm{y}}$ & $0^{y}$ & --- \\
\hline $\mathrm{R}$ & 18 & 23 & 121 & 126 & 1.1 & 38 & 40 & 48 & 38 & 16 & 21 Aug. & 5 & 3 & 1.6 \\
\hline \multicolumn{15}{|c|}{ Lavaltrie } \\
\hline$A B$ & 26 & 39 & 130 & 128 & 1.1 & 33 & 35 & 56 & 43 & 16 & 26 July & 25 & 50 & 2.5 \\
\hline $\mathrm{H}$ & 46 & 60 & 144 & 143 & 1.1 & 42 & 43 & 48 & 44 & 17 & 6 Aug. & 8 & 33 & 2.3 \\
\hline $\mathrm{R}$ & 26 & 40 & 137 & 141 & 1.1 & 40 & 44 & 51 & 42 & 16 & 26 July & 20 & 52 & 1.9 \\
\hline \multicolumn{15}{|c|}{ Kemptville } \\
\hline $\mathrm{AB}$ & 12 & 18 & 111 & 121 & 1.1 & 32 & 37 & 46 & 52 & 17 & 15 July & $\mathrm{ND}^{\mathrm{x}}$ & 43 & 2.1 \\
\hline $\mathrm{H}$ & 26 & 43 & 120 & 139 & 1.2 & 39 & 43 & 46 & 43 & 17 & 10 Aug. & ND & 14 & 2.1 \\
\hline $\mathrm{R}$ & 10 & 35 & 132 & 136 & 1.1 & 43 & 40 & 43 & 42 & 16 & 23 July & ND & 21 & 1.7 \\
\hline \multicolumn{15}{|c|}{ Cambridge } \\
\hline $\mathrm{AB}$ & 28 & 23 & 104 & 117 & 1.1 & 31 & 37 & 32 & 42 & 14 & 7 Aug. & 52 & 48 & 2.0 \\
\hline $\mathrm{H}$ & 55 & 38 & 113 & 128 & 1.1 & 42 & 44 & 27 & 31 & 16 & 15 Aug. & 31 & 34 & 1.3 \\
\hline $\mathrm{R}$ & 45 & 46 & 114 & 127 & 1.0 & 37 & 42 & 30 & 34 & 15 & 2 Aug. & 39 & 44 & 1.3 \\
\hline \multicolumn{15}{|c|}{ Vineland } \\
\hline $\mathrm{AB}$ & 40 & 46 & 125 & 118 & 1.3 & 34 & 37 & 45 & 45 & 16 & 5 Aug. & 61 & 46 & 2.6 \\
\hline $\mathrm{H}$ & 61 & 59 & 139 & 136 & 1.4 & 42 & 45 & 38 & 51 & 19 & 10 Aug. & 47 & 42 & 2.1 \\
\hline $\mathrm{R}$. & 40 & 56 & 145 & 141 & 1.3 & 40 & 44 & 53 & 50 & 18 & 2 Aug. & 59 & 41 & 2.0 \\
\hline \multicolumn{15}{|c|}{ Harrow } \\
\hline $\mathrm{AB}$ & 33 & 32 & 108 & 121 & 1.1 & 33 & 40 & 24 & 41 & 15 & 5 Aug. & 31 & 56 & 2.2 \\
\hline $\mathrm{H}$ & 65 & 49 & 119 & 110 & 1.1 & 39 & 45 & 33 & 29 & 15 & 23 Aug. & 23 & 28 & 1.8 \\
\hline $\mathbf{R}$ & 42 & 36 & 121 & 137 & 1.1 & 38 & 47 & 27 & 37 & 14 & 7 Aug. & 42 & 50 & 1.7 \\
\hline $\mathrm{SE}^{\mathrm{w}}$ & \multicolumn{2}{|c|}{3} & \multicolumn{2}{|c|}{5} & 0.03 & \multicolumn{2}{|c|}{1} & \multicolumn{2}{|c|}{2} & 0.5 & 2 & \multicolumn{2}{|l|}{ 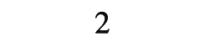 } & 0.08 \\
\hline
\end{tabular}

${ }^{\mathrm{z}}$ Cultivar $\times$ location $\times$ year was significant for all components except cane diameter, number of fruiting laterals per cane, and berry weight. However, significant cultivar $\times$ location interactions were found for cane diameter, number of fruiting laterals per cane, and berry weight. Therefore, mean values for cultivar $\times$ location were pooled over years.

y No fruit were harvested in New Liskeard due to early frosts.

${ }^{\mathrm{x}} \mathrm{ND}=$ no data from Kemptville in 1989.

$\mathrm{w}_{\mathrm{SE}}$ is the standard error for differences between entry means for the three cultivars grown at six locations in 1989 and 1990 . SE for cane diameter, number of fruiting laterals per cane, and berry weight were pooled over years. 
density is an important yield component with a positive effect on yield in summer-bearing (Buszard, 1986; Nehrbas and Pritts, 1988) and PF red raspberries, including 'Heritage' and 'Redwing' (Hoover et al., 1988). In the present study, cane density was poorly correlated to yield ( $r=0.04, \mathrm{P}=0.80, \mathrm{n}=74)$. However, the lack of consistency with previously published reports may be due to the significant effect of differing environments, since it is likely that cane density within a particular environment does effect yield. The cane counts for 'Autumn Bliss' were $\approx 41 \%$ less at the two northern locations (New Liskeard and Kemptville), and canes failed to emerge in two of the five plots at New Liskeard in 1990. This suggests that the 'Autumn Bliss' root system may not be as coldtolerant as the other two cultivars.

Cane height and node count per cane for the three cultivars varied with growing season and location (Table 2). The range in cane height between locations was $37 \%, 33 \%$, and $52 \%$ greater in 1989 than in 1990 for 'Autumn Bliss', 'Heritage', and 'Redwing', respectively, while the node count per cane was variable in both years. These results suggest that cane height, or more specifically, internode length of 'Redwing', was more sensitive to climatic variation than 'Autumn Bliss' or 'Heritage'. In PF red raspberries,
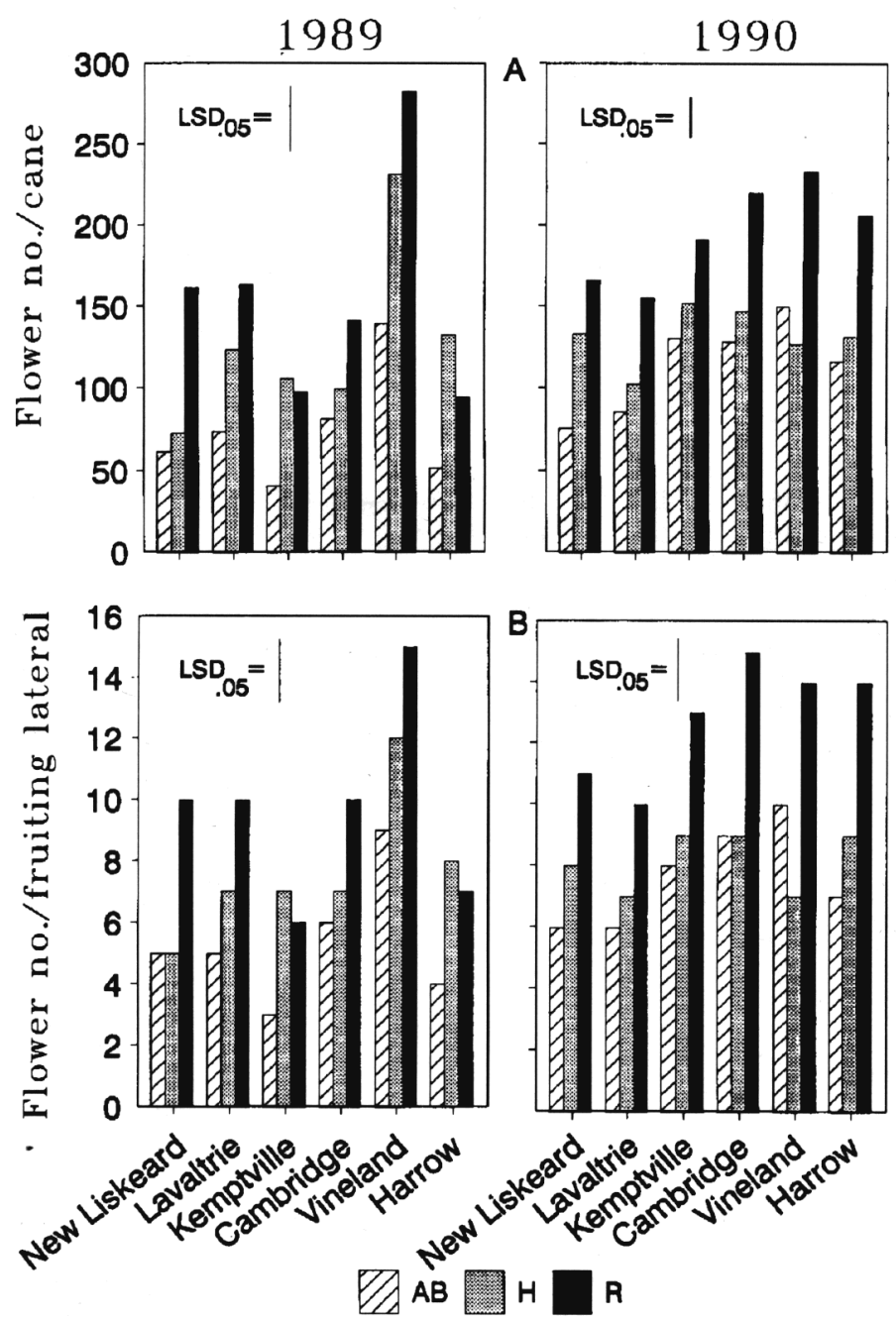

Fig. 1. Total number of flowers per cane (A) and number of flowers per fruiting lateral (B) at each of six locations for 'Autumn Bliss' (AB), 'Heritage' (H), and 'Redwing' (R) during 1989 and 1990. Bars represent the mean of 20 canes at each location. Vertical line represents the least significant difference (LSD) for the comparisons between cultivars over all locations $(P=0.05)$. the number of reproductive nodes as measured by the number of fruiting laterals is more important to yield potential than cane height or node count per cane. Hoover et al. (1988) found that the percentage of fruiting nodes had a highly significant and positive effect on yield for all genotypes tested. In the present study, the percentage of fruiting laterals varied from a minimum of $30 \%$ for 'Redwing' at Harrow in 1990 to a maximum of $48 \%$ for 'Autumn Bliss' at Lavaltrie in 1989. Interestingly, yields for these cultivars in these environments were either reduced or increased proportional to their percentage of fruiting laterals. Although this. result agrees with those of Hoover et al. (1988), the number of flowers per fruiting lateral, which is discussed later, was found to positively influence yield more than the percentage of fruiting laterals.

Analysis of the reproductive components revealed significant cultivar $\times$ location $\times$ year interactions for all components except number of fruiting laterals per cane and berry weight (Table 2). Significant location $\times$ cultivar and year $\times$ location interactions were found for the number of fruiting laterals per cane, while berry weight also had a significant year $\times$ cultivar interaction. Similar to the vegetative components, the range in magnitude between loca-
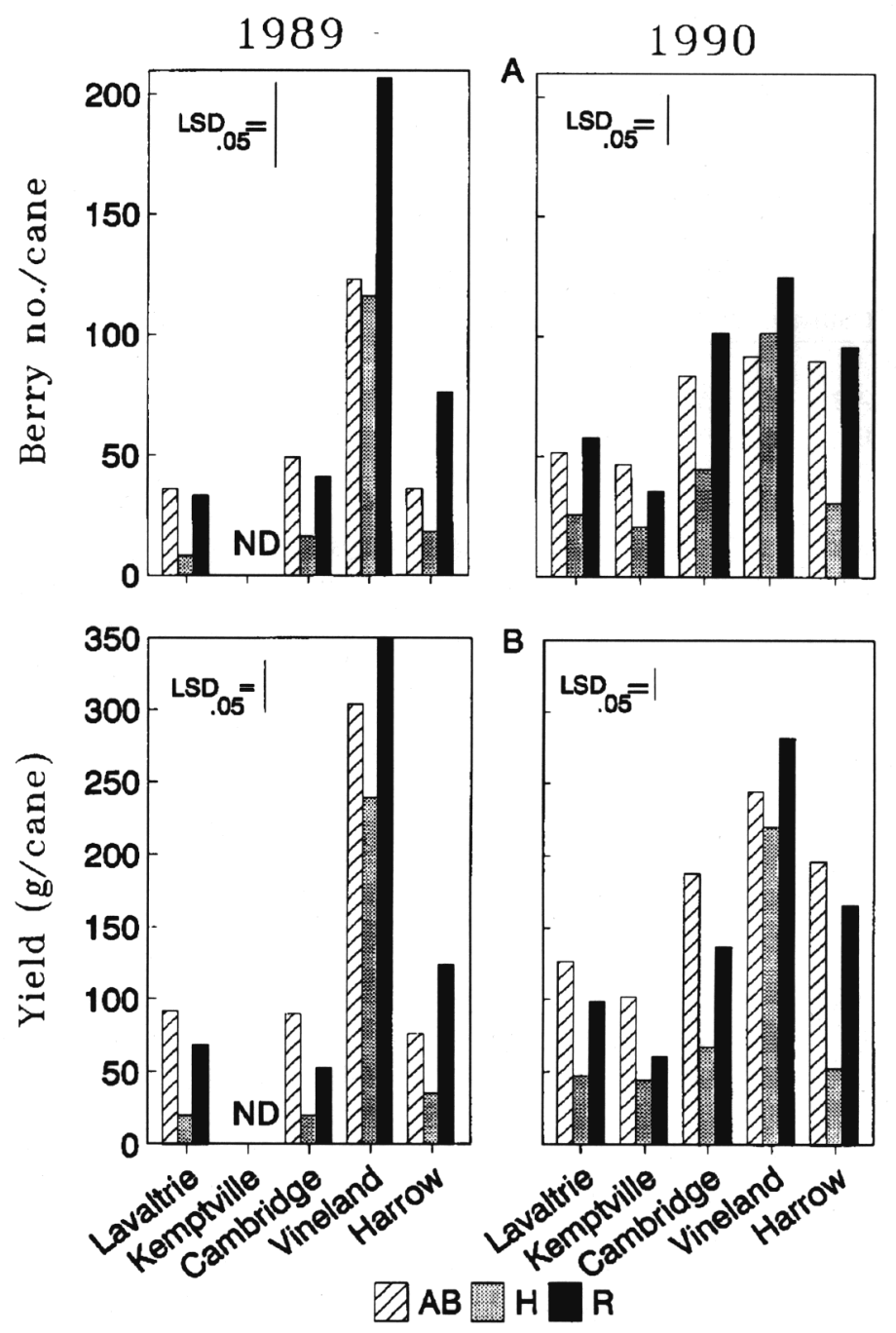

Fig. 2. Total number of berries per cane harvested (A) and yield (grams/cane) at each of six locations for 'Autumn Bliss' (AB), 'Heritage' $(H)$, and 'Redwing' (R) during 1989 and 1990. Bars represent the mean of 20 canes at each location. No data (ND) were collected at Kemptville in 1989. Vertical line represents the least significant difference (LSD) for the comparisons between cultivars over all locations $(P=0.05)$. 
tions was less in 1990 than in 1989 for total number of flowers per cane, number of flowers per lateral, length of the fruiting section, number of berries harvested, yield, and harvest duration (Table 2, Figs. 1 to 3 ).

Total flower number is determined by number of fruiting laterals and number of flowers per fruiting lateral. In the present study, the variability in total flower count was more dependent on number of flowers per fruiting lateral than on number of fruiting laterals for all three cultivars (Fig. 1, Table 2). This difference is illustrated in Fig. 1B, where the number of flowers per fruiting lateral followed closely the response of total flower count to change in environments (Fig. 1A). This result suggests that flower count per fruiting lateral was responsible for the majority of the genotype $\mathrm{x}$ environment interactions found in total flower count. Similarly, the number of berries per fruiting lateral, which are dependent on flower count per fruiting lateral, has been reported to have a greater influence on yield than the percentage of fruiting laterals (Hoover et al., 1988). Of the three cultivars, 'Redwing' produced the highest number of flowers per cane and per fruiting lateral in all locations in 1990 and in four of the six locations in 1989 (Fig. 1 A and B). Interestingly, a greater fluctuation in flower number was reported for all cultivars in 1989 than in 1990 (Fig. 1 $\mathrm{A}$ and $\mathrm{B})$.

Two yield components, berry weight and count, differed between 'Autumn Bliss' and 'Redwing'. Berry weight for 'Autumn Bliss' averaged $2.3 \mathrm{~g}$ compared to $1.7 \mathrm{~g}$ for 'Redwing' (Table 2), while berry count per cane for 'Autumn Bliss' and 'Redwing' averaged 107 and 166, respectively (Fig. 2A). In some location/ years, berry weight between cultivars differed by as much as $0.6 \mathrm{~g}$, while berry count differed by $>100$ berries per cane. Berry count was a more important determinant of yield than berry weight. Berry count and yield were not included for New Liskeard, because too few fruit were harvested due to early frosts (Fig. 2). Generally, the highest yielding cultivars also had the highest berry count per cane. Overall, 'Heritage' had the fewest number of berries (Fig. 2A) and was the lowest yielding cultivar (Fig. 2B). However, the yield potential for this late maturing cultivar was often not reached due to poor weather late in the season. Of the three cultivars, 'Redwing' had the greatest variability in berry count and yield among the different environments (Fig. 2 A and B). Only at Vineland in 1990 did 'Redwing' achieve the highest yield of the three cultivars, due to a higher berry count. Otherwise, the yields of 'Autumn Bliss' and 'Redwing' were similar.

Nowhere was the difference between local environments greater for flower count, berry count, and yield than at Cambridge and Vineland in 1989 (Figs. 1 and 2). For example, yields at Cambridge were $70 \%$ lower than at Vineland, although the two locations differ by only 15 ' $\mathrm{N}$ latitude (Fig. 2B). Once again, the vast differences reported in 1989 were not found in 1990. Vineland was the only location that had daily trickle irrigation and was adjacent to the moderating effects of Lake Ontario. The other locations were more inland and received overhead irrigation only as required to supplement rainfall. Whether these differences were due to lower air temperatures or increased water availability is not readily determined. However, the positive influence of irrigation on raspberries during relatively dry years has been documented (Goode and Hyrycz, 1968; Kongsrud, 1969).

When the total number of flowers, which is an indication of potential yield (Fig. 1A), was compared to the actual number of berries harvested (Fig. 2A), the percentage of the potential crop harvested (berries harvested per total number of flowers x 100) varied among cultivars, locations, and years. At Vineland in 1989, 'Autumn Bliss', 'Heritage', and 'Redwing' had 88\%, 50\%, and
$73 \%$ of their potential crop harvested, respectively, while at Cambridge; the same three cultivars reached $60 \%, 16 \%$, and $29 \%$ of their yield potential, respectively. 'Redwing' had the greatest loss of yield potential of the three cultivars when comparing the potential crop harvested between these two locations: $44 \%$ difference for 'Redwing' vs. 28\% and 34\% for 'Autumn Bliss' and 'Heritage', respectively. Whether 'Redwing' responds more to supplemental irrigation and lower air temperatures than either 'Autumn Bliss' or 'Heritage' is discussed in Privé et al. (1993).

On average, the number of days between FB and first harvest in 1990 was 27, 34, and 34 for 'Autumn Bliss', 'Heritage', and 'Redwing', respectively. Except for Harrow, there was also, on average, a reduction in the number of days between FB and first harvest as the locations progressed from north to south. This interval between FB and first harvest was 40, 36, 29, 25, and 30 days for Kemptville, Lavaltrie, Cambridge, Vineland, and Harrow, respectively. Although the date of FB is important in determining whether the yield potential of a genotype is reached, a late maturing cultivar, such as 'Heritage', would certainly benefit from a shorter interval between FB and first harvest. This strategy could be incorporated into a breeding program for the selection of earlier maturing genotypes.

The difference in relative ranking found by Hoover et al. (1989) in the approximate first harvest dates for 'Heritage' and 'Redwing' in New York vs. Minnesota or Michigan was not found in this study. Although a range of latitudes was sampled, 'Heritage' was always the latest-bearing of the three cultivars, while 'Autumn Bliss' and 'Redwing' were earlier in their dates of full bloom and first harvest. 'Autumn Bliss' was usually the first cultivar to bear fruit, while 'Redwing' was 3 to 21 days later. Only at Harrow in 1989 did harvests for 'Redwing' begin before those of 'Autumn Bliss' (Fig. 3). At Harrow in 1990, the dates of first harvest for
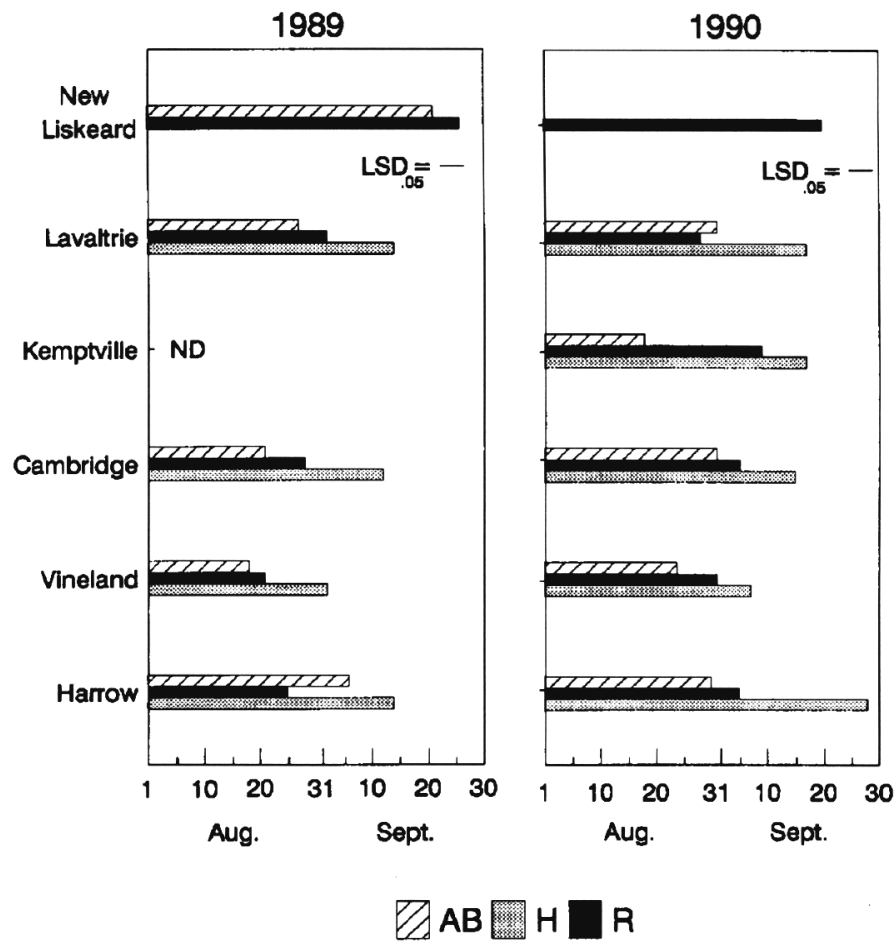

Fig. 3. Dates of first harvest for 'Autumn Bliss' (AB), 'Heritage' (H), and 'Redwing' (R) in 1989 and 1990. Horizontal line represents least significant difference (LSD) for comparison of means between cultivars and locations. No data (ND) was available for Kemptville in 1989. 
'Heritage' may have been delayed due to a change in ontogeny caused by a leaf hopper infestation in July. The number and length of harvests were limited at New Liskeard due to late production and early frosts.

In summary, the information from the present study suggests that the performance of the three cultivars was significantly influenced by their environment. Although 'Redwing' showed the greatest yield potential (i.e., highest number of flowers and fruit per cane), it also produced the lightest berries and had the greatest variability among locations. In contrast, 'Autumn Bliss' had fewer flowers and fruit per cane, but had, on average, the heaviest berries and was the least variable among locations. Therefore, although yields were similar between these two cultivars, the potential crop harvested from 'Autumn Bliss' was larger than from 'Redwing'. Likewise, 'Autumn Bliss' had the best performance for many of the yield components in this study. As for 'Heritage', this study confirms that its full crop potential is often not realized in many northern environments due to its late-bearing habit (Daubeny et al., 1992). The range in variability for the vegetative and reproductive components differed between the 2 years. Our companion paper (Privé et al., 1993) discusses which environmental factors most influence these yield components.

\section{Literature Cited}

Buszard, D.J.I. 1986. The effect of management system on winter survival and yield of raspberries in Quebec. Acta Hort. 183:175-182.

Crandall, P.C., J.D. Chamberlain, and K.A. Biderbost. 1974. Cane characteristics associated with berry number of red raspberry. J. Amer. Soc. Hort. Sci. 99:370-372.

Daubeny, H.A., K. Maloney, and G.R. McGregor. 1992. 'Heritage' red raspberry. Fruit Var. J. 46:2-3.

Goode, J.E. and K.J. Hyrycz. 1968. The response of Malling Jewel and Malling Exploit raspberries to different soil moisture conditions and straw mulching. J. Hort. Sci. 43:215-230.

Hoover, E., J. Luby, D. Bedford, and M. Pritts. 1988. Vegetative and reproductive yield components of primocane-fruiting red raspberries. J. Amer. Soc. Hort. Sci. 113:824-826.

Hoover, E., J. Luby, D.S. Bedford, M. Pritts, E. Hanson, A. Dale, and H. Daubeny. 1989. Temperature influence on harvest date and cane development of primocane-fruiting red raspberries. Acta Hort. 262:297-303. Keep, E. 1988. Primocane (autumn)-fruiting raspberries: A review with particular reference to progress in breeding. J. Hort. Sci. 63:1-18.

Keep, E., J.H. Parker, and V.H. Knight. 1984. 'Autumn Bliss', a new early autumn-fruiting raspberry. Annu. Rpt. E. Malling Res. Sta. for 1983, p. 191-192.

Kongsrud, K.L. 1969. Vatningsforsk med bringebaer (irrigation experiments with raspberries). Forskning og Fors $\varnothing \mathrm{k}$ i Landbruket 20:435416.

Louws, F. 1991. Growing red raspberries in Ontario. Ont. Ministry Agr. Food Pub. 105.

Luby, J.J., E.E. Hoover, D.S. Bedford, S.T. Munson, W.H. Gray, D.K. Wildung, and C. Stushnoff. 1987. 'Redwing' raspberry. HortScience 22:681-682.

Mawe, T. and Abercrombie. 1778. Universal gardener and botanist; or a General dictionary of gardening and botany, London.

Nehrbas, S.R. and M.P. Pritts. 1988. Effect of training system on performance of hand-harvested summer-bearing raspberries. HortScience 23:126-127.

Privé, J.-P, J.A. Sullivan, J.T.A. Proctor, and O.B. O’Brien. 1993. Climate influences vegetative and reproductive components of primocane-fruiting red raspberry cultivars. J. Amer. Soc. Hort. Sci. 118:393-399.

SAS Institute. 1987. SAS/STAT guide for personal computers. version 6 (ed.). SAS Institute, Cary, N.C.

Steel, R.G.D. and J.H. Torrie. 1980. Principles and procedures of statistics. McGraw-Hill. New York. 